\title{
Main epidemiological features of COVID-19 cases admitted in a first line defence hospital from Bucharest, Romania
}

\author{
Niculae Ion Nedelcu', Radu Robert Mateescu', Emanoil Ceausu ${ }^{1,3,4}$, \\ Petre lacob Calistru², Simin-Aysel Florescu1,3 \\ 1"Dr. Victor Babes" Infectious and Tropical Diseases Hospital, Bucharest, Romania \\ 2"Dr. Victor Babes" Hospital General Foundation, Bucharest, Romania \\ 3"Carol Davila" University of Medicine and Pharmacy, Bucharest, Romania \\ ${ }^{4}$ Academy of Medical Sciences of Romania
}

\begin{abstract}
In this retrospective unicenter study we aimed to outline the key features of the first 100 cases of COVID-19 hospitalized in our clinic after designation of it as front line unit for hospitalization of these cases. Thus, the average age of cases was 44.7 years (SD: 15.9 ) and the prevalence of female was $57.4 \%$. By age groups, prevalence of young patients $(7.8 \%)$ was significantly $(p<0.05)$ lower than the prevalence of adult patients $(77.2 \%)$. The most prevalent occupation $(31.7 \%)$ was healthcare worker. The most frecvent exposure to source of infection was represented by attending healthcare facilities (44.6\%), followed by having contact with COVID-19 confirmed/suspect case (30.7\%), and recent international travel (18.8\%). Of the $30 \%$ of cases in which at least one health precondition was recorded the most prevalent $(13.9 \%)$ of such condition was chronic cardiovascular disease including high blood presure. In regard with severity, to note that 6 patients died within 14 days of hospital admission, all fatalities have occurred in very old patients and $83.3 \%$ of them had chronic kidney disease. In the end, we express the hope that data outlined in this paper will help for better management of COVID-19 pandemic.
\end{abstract}

Keywords: COVID-19, SARS-CoV-2, first line defence hospital, hospital admission, epidemiological features

\section{BACKGROUND}

On January 30, 2020, The World Health Organization (WHO) declared the outbreak provoked by the novel coronavirus (2019-nCoV) a public health emergency of international concern (1). On March 11, 2020, WHO characterised COVID-19 as a pandemic (2). This follows after, on the last day of 2019, Chinese authorities officially announced that they were managing an outbreak of pneumonia with an unknown cause. On January 7, 2020, the idiopathic pneumonia was reported to have been caused by a new coronavirus, and information regarding the organism has been made available to researchers around the world (3).
WHO tentatively named this new virus as the 2019 novel coronavirus (2019-nCoV). As epidemiologic characteristics of this new disease are unknown, they are being investigated based on comparisons with the clinically similar Severe Acute Respiratory Syndrome and the Middle East Respiratory Syndrome. Rapid investigation and determination of epidemiologic characteristics of new infectious diseases is crucial in order to limit the transmission and to attain a desirable treatment outcomes through early diagnosis and management. Sharing of crucial data by epidemiologists around the world is highly critical and it could help to definitively determine characteristics of this new in- 
fectious disease and to prevent its additional spread accordingly.

Similarly with other works based on assesment of a small sample of cases at the beginning of epidemic $(3,4)$, this paper is an risk assessment of the first 100 of COVID-19 cases admitted in our first line defence infectious and tropical diseases clinic, cases in which the infection source, the mechanism of transmision and susceptible host were clarely discened making possible to generate incidences, prevalences, 95\% confident limits and also regression coeficients for trend. These parameters, which are not simply to be calculate during the community transmision phase of the patogen, are needed by policy makers to make estimations of supplies and also to take highlty effective control decisions (including unfriendly) in accordance with field reality, avoiding in this way improvisations and guessing.

\section{OBJECTIVE}

Aim of this work was to emphasize the main epidemiological features of COVID-19 cases admitted in our 490 beds first line system hospital in order to provide basically notions for control measures to the persons in charge.

\section{METHODS}

\section{Data set}

In Bucharest, Romania, timely evolving of COVID-19 epidemic/pandemic implied appearance in the first tempo of imported cases, followed by a second tempo, dominated by locally transmited cases with easily to recognisable source of infection (e.g. healthcare facility or confirmed/suspect persons) and the third tempo defined as community transmission period, dominated by cases to whom it is imposible to associate a sourse and a transmission mechanism of infection. Our sample includes COVID-19 cases, belonging to the first and second tempos of epidemic, cases addmited in our hospital between 05/03/2020 and $24 / 03 / 2020$.

\section{Source of data}

All data were withdrawed from the case based surveillance form (5), which represents the legal document destinated to vehiculate socio-demografic, clinical and epidemiologcal information related to each confirmed COVID-19 case, from operational level up to decision taken level.

\section{Case definition}

A confirmed COVID-19 case is a Bucharest municipality resident, with at least one positive result by real-time reverse-transcription-polymerase-chainreaction (RT- PCR) assay for 2019-nCoV or a genetic sequence that matches 2019-nCoV (6).

\section{Time profile}

Epidemic curve shape was built through assortment of cases by a calendar week's rank based on hospital admission date (e.g. a case with hospital admission date of March $12^{\text {th }}$ was allocated to the week ranked $\left.11^{\text {th }}\right)$. The trend in the number of cases per week was assesed by linear regression.

\section{Data management}

An EpiInfo data base (7) was powered with data contained in the surveillance form and interogated as needed. Signification - software default of 0.05 was accepted for statistical signification.

\section{Sampling}

It was not necessary as all cases fullfiled including criteria were enlisted consecutively in the study set.

\section{Ethical approval}

Data collection of casses was determinated by the relevant National Task Force to be part of a continuing public health outbreak investigation and were thus considered exempt from institutional review board approval.

\section{RESULTS}

A total of 101 cases of COVID-19 fulfilled including criteria; the mean age of cases was 44.7 years (SD: 15.9) (IQR: 36-53 years);

By gender, 58 of the patients were female and 43 were male (table 1); incidence of cases by gender was similar: (5.10 vs 4.31) [(relative risk (RR): $1.18 ; 95 \%$ confidence interval (CI): $(0.80-1.71) ; \chi 2: 0.70$; $\mathrm{p}$ value: 0.4031)]. 
TABLE 1. Prevalence (\%) and incidence of the COVID-19 admitted cases by gender

\begin{tabular}{|l|c|c|}
\hline Gender & $\begin{array}{c}\text { No. (percents) } \\
\text { (95\% confidence limits) }\end{array}$ & $\begin{array}{c}\text { Incidence } \\
\text { (cases/105 habitants) }\end{array}$ \\
\hline Female & $58(57.4 \%)(47.2 \%-67.2 \%)$ & 5.10 \\
\hline Male & $43(42.6 \%)(32.8 \%-52.8 \%)$ & 4.31 \\
\hline Total & $101(100.0 \%)$ & 4.74 \\
\hline
\end{tabular}

By age groups the most prevalent was "Adult" group (77.2\%) (table 2); the higher incidence was also calculated in the "Adult" group of age.

Incidence of cases in "Adult" was statistical significant higher than in the "Junior" group (5.59 vs. 2.17) [(RR: 2.57; 95\%CI: (1.24-5.31); $\chi 2: 6.94$; p: 0.0084], but was similar with incidence in the "Senior" age group [(RR: 1.38 ; 95\% CI: $(0.79-2.40) ; \chi 2$ : $1.32 ; \mathrm{p}: 0.2512]$.

TABLE 2. Prevalence (\%) and incidence of the cases by age group

\begin{tabular}{|l|c|c|}
\hline $\begin{array}{l}\text { Age group ID } \\
\text { and range }\end{array}$ & $\begin{array}{c}\text { No. (percents) } \\
\text { (95\% confidence limits) }\end{array}$ & $\begin{array}{c}\text { Incidence } \\
\text { (cases/10 } \\
\text { habitants) }\end{array}$ \\
\hline Junior (0-19 yrs) & $8(7.9 \%)(3.5 \%-15.0 \%)$ & 2.17 \\
\hline Adult (20-64 yrs) & $78(77.2 \%)(67.8 \%-85.0 \%)$ & 5.59 \\
\hline Senior $(65+$ yrs) & $15(14.9 \%)(8.6 \%-23.3 \%)$ & 4.05 \\
\hline Total & $101(100.0 \%)$ & 4.74 \\
\hline
\end{tabular}

\section{Exposure}

Prevalence of the cases by the nature of exposure ranged from $5.9 \%$ in community aquired class until to $44.6 \%$ for exposure in the healthcare facilities class (table 3).

TABLE 3. Prevalence (\%) of the cases by exposure type - sorted in descended order

\begin{tabular}{|c|c|c|}
\hline $\begin{array}{l}\text { Circumstances of exposure } \\
\text { within } 14 \text { days prior to } \\
\text { hospital admission -*) }\end{array}$ & $\begin{array}{c}\text { No. } \\
\text { (percents of } \\
\text { total) }\end{array}$ & $\begin{array}{c}95 \% \\
\text { confidence } \\
\text { limits }\end{array}$ \\
\hline A ended healthcare facility & 45 (44.6\%) & $36.7 \%-54.8 \%$ \\
\hline $\begin{array}{l}\text { Had contact with con } \\
\text { suspect case }\end{array}$ & $31(30.7 \%)$ & $\begin{array}{c}21.9 \%- \\
40.7 \%\end{array}$ \\
\hline $\begin{array}{l}\text { Undertook recent interna } \\
\text { travel }\end{array}$ & 回 19 (18.8\%) & $11.7 \%-27.8 \%$ \\
\hline $\begin{array}{l}\text { None of above (community } \\
\text { aquired) }\end{array}$ & $6(5.9 \%)$ & $(2.2 \%-12.5 \%)$ \\
\hline Total & $101(100.0 \%)$ & - \\
\hline
\end{tabular}

*) Selected the most plausible exposure when multiple were reported

Prevalence of exposure class by gender was similar [ $\chi 2: 5.05$; degree of freedom (df): 3; p: 0.1676], but the prevalence of cases by age group differed significantly [ $\chi 2: 13.63$; df: 6; p: 0.0340]. The most prev- alent exposure in the "Junior" group (50.0\%) was by contact with a confirmed/suspect case, while the most prevalent exposure of the "Adult" group (47.4\%) and "Senior" group (46.7\%) was consummed by attending a healthcare facilities (table not shown here).

\section{Occupation}

Healthcare worker was found the most prevalent occupation (31.7\%) (table 4).

TABLE 4. Cases' prevalence by occupation - sorted in descended order, except cathegory "Others"

\begin{tabular}{|l|c|c|}
\hline Occupation * & $\begin{array}{c}\text { No. } \\
\text { (percents of } \\
\text { total) }\end{array}$ & $\begin{array}{c}\text { 95\% } \\
\text { confidence } \\
\text { limits }\end{array}$ \\
\hline Healthcare worker & $32(31.7 \%)$ & $22.8 \%-41.7 \%$ \\
\hline Re ed & $14(13.9 \%)$ & $7.8 \%-22.2 \%$ \\
\hline Public services worker & $9(8.9 \%)$ & $4.2 \%-16.2 \%$ \\
\hline Unemployed & $7(6.9 \%)$ & $2.8 \%-13.8 \%$ \\
\hline Student (6-24 years of age) & $7(6.9 \%)$ & $2.8 \%-13.8 \%$ \\
\hline $\begin{array}{l}\text { Prescool child } \\
\text { (aged under 7 years) }\end{array}$ & $3(3.0 \%)$ & $0.6 \%-8.4 \%$ \\
\hline Other occupa & $29(28.7 \%)$ & $20.1 \%-38.6 \%$ \\
\hline Total & $101(100.0 \%)$ & - \\
\hline
\end{tabular}

\section{Health preconditions}

No health precondition listed in the surveillance form was found in a number of 70 of our cases $(69,9 \%)$; for the rest of cases the most prevalent noted health precondition was chronic cardiovascular disease including high blood pressure (13.9\%) (Table 5).

TABLE 5. Health preconditions associated with COVID-19 cases, sorted in descended order, except cathegory "None"

\begin{tabular}{|l|c|c|}
\hline Health preconditions * & $\begin{array}{c}\text { No. } \\
\text { (percents of } \\
\text { total) }\end{array}$ & $\begin{array}{c}\text { 95\% } \\
\text { confidence } \\
\text { limits }\end{array}$ \\
\hline $\begin{array}{l}\text { Chronic cardiovascular disease } \\
\text { including HBP }\end{array}$ & $14(13.9 \%)$ & $7.8 \%-22.2 \%$ \\
\hline $\begin{array}{l}\text { Oncologic/haematologic chronic } \\
\text { disease }\end{array}$ & $5(5.0 \%)$ & $1.6 \%-11.2 \%$ \\
\hline $\begin{array}{l}\text { Chronic kidney disease including } \\
\text { dyalised }\end{array}$ & $5(5.0 \%)$ & $1.6 \%-11.2 \%$ \\
\hline Chronic liver disease & $2(2.0 \%)$ & $0.2 \%-7.0 \%$ \\
\hline Imunode & $2(2.0 \%)$ & $0.2 \%-7.0 \%$ \\
\hline Type 2 diabetes & $1(1.0 \%)$ & $0.0 \%-5.4 \%$ \\
\hline $\begin{array}{l}\text { Chronic pulmonary disease } \\
\text { including BPOC }\end{array}$ & $1(1.0) \%)$ & $0.0 \%-5.4 \%$ \\
\hline Pregnancy & $1(1.0 \%)$ & $0.0 \%-5.4 \%$ \\
\hline None & $70(69.9 \%)$ & $59.3 \%-78.1 \%$ \\
\hline Total & $101(100.0 \%)$ & - \\
\hline
\end{tabular}

*) There were selected the most severe ones, if multiple health precondition were reported per subject. 


\section{Signs/Simptoms}

Due to nature of case definition based solely on laboratory result we excluded analysis of signs/ simptoms found at hospital admission.

\section{Severity}

6 patients died within 14 days of hospital admission - below are listed the main features of died patients:

- Cases fatality rate (CFR): $5.9 \%$ (95\% CL:2.2\%$12.5 \%)$

- $83.3 \%$ of the fatal cases reported with chronic kidney disease

- All fatal cases (100.0\%) belog to the "Senior" age group

- Gender was distributed equal between fatal cases.

\section{Time profile}

During the first three consecutive weeks the frequence of COVID-19 cases admitted in hospital increased from 4 cases in the week ranked $10^{\text {th }}$ until to 76 cases in the most recent complete week (Table 6) .The results of linear regression of cases frequencies per week rank were as follows: correlation coefficient $\left(\mathrm{r}^{2}\right)$ : 1.00; regression coeficient (ß): 36 cases; std error: 0.577 ; F-test: 3888.0 ; $p$ value: 0.0000 .

TABLE 6. Frequence of new cases per calendar week rank

\begin{tabular}{|c|c|}
\hline Week rank (date end Sunday) & No. hospital admissions \\
\hline $10^{\text {th }}(08 / 03)$ & 4 \\
\hline $11^{\text {th }}(15 / 03)$ & 41 \\
\hline $12^{\text {th }}(22 / 03)$ & 76 \\
\hline $13^{\text {th }}(29 / 03)^{*}$ & 17 \\
\hline
\end{tabular}

*) incomplete - see study sample' size

\section{DISCUSSION}

\section{Age \& gender}

In our data set we found an average age of 44,7 years (SD: 15.9) including 58 males and 54 women By contrast, at the beginning of the COVID-19 outbreak, Chinese researchers described an average age of 55.5 years (SD 13.1) including 67 men and 32 women $(4,8)$. We can speculate that the older patients might have increased CFR in China. Also to note the weak representation of children and teenagers (7.8\%) in our data set.

\section{Occupation}

The most striking result of our assesment was the unexpected high prevalence of healthcare worker among reported ocupations $(31.7 \%)$. We think that this is due a superspreading effect, an phenomenon reported frequently at the beginning of an epidemic $(9,10)$. However, we like to stress that "longer duty hours, and suboptimal hand hygiene after contacting with patients were linked to COVID-19" were validated risk factors between healthcare workers (11).

\section{Cases fatality rate}

CFR found in this report is higher than the one reported in China (12). However, to note that the total number of COVID-19 cases (i.e. CFR's denominator) is likely higher due to inherent difficulties in identifying and counting mild and asymptomatic cases.

\section{Time profile}

Because of the superspread effect, we avoided to proceed to an estimation of reproductiv number (Ro) as other researcers did (13). Instead we scrutined the trend based on linear regression, which confirmed our empirical observation that in the first 3 consecutive weeks of the epidemic there was a strong growth of weekly number of cases $(\mathrm{r} 2:+0.95)$; prognosed rate of weekly increase was $\beta=30.5$ cases.

\section{CONCLUSION}

In this retrospective unicenter study we aimed to outline the key features of the first 100 cases of COVID-19 hospitalized in our clinic after designation of it as front line unit for hospitalization of these cases.

We expressesed the hope that data outlined in this paper will help for better management of COVID-19 pandemic.

\section{REFERENCES}

1. World Health Organization. Statement on the second meeting of the International Health Regulations (2005) Emergency Committee regarding the outbreak of novel coronavirus (2019-nCoV) https://

www.who.int/news-room/detail/30-01-2020-statement-on-the-secondmeeting-of-the-international-health-regulations-(2005)-emergencycommittee-regarding-the-outbreak-of-novel-coronavirus-(2019-ncov). 
2. World Health Organization. WHO characterizes COVID-19 as pandemic https://who.paho.org/hq/index.php?option=com_content\&vi ew=article\&id=1576\&ltemid=1926\&lang=en .

3. Carlos WG, Dela Cruz CS, Cao B, Pasnick S, Jamil S. Novel Wuhan (2019-nCoV) coronavirus. Am J Respir Crit Care Med. 2020; 201:p7-p8.

4. Chen N, Zhou M, Dong X, Qu J et al. Epidemiological and clinical characteristics of 99 cases of 2019 novel coronavirus pneumonia in Wuhan, China: A descriptive study Lancet. 2020; 395(10223):507-513.

5. INSP - Metodologia de supraveghere a sindromului respirator $\mathrm{cu}$ noul coronavirus - http://www.cnscbt.ro/index.php/metodologii/ infectia-2019-cu-ncov/1650-metodologia-de-supraveghere-a-covid19-actualizare-10-04-2020-1/file.

6. Laboratory diagnosis for novel coronavirus. WHO 2020 (https://www. who.int/healt-topics/coronavirus/laboratory-diagnostics-for-novelcoronavirus.

7. CDC: Dean AG, Arner TG, Sunki GG, Friedman R, Lantinga M, Sangam S, Zubieta JC, Sullivan KM, Brendel KA, Gao Z, Fontaine N, Shu M, Fuller G, Smith DC, Nitschke DA, and Fagan RF. Epi Info ${ }^{\mathrm{TM}}$, a database and statistics program for public health professionals. CDC, Atlanta, GA, USA, 2011.
8. Zhou P, Huang Z, Xiao Y, Huang X. Protecting Chinese Healthcare Workers while combating the 2019 novel coronavirus. Infect Control \& Hospital Epidemiology. 2020:1-4.

9. Al-Tawfig JA, Rodriguez-Morales AJ. Super-spreading events and contribution to transmission of MERS, SARS, and COVID-19. J Hosp Infect. 2020;S0195-6701(20)30177-8.

10. Kim $Y$, Ryu H, Lee S. Agent-based modeling for super-spreading events: A case study of MERS-Cov transmission dinamics in the Republic of Korea. Int J Environ Res Public Health. 2018;15(11).

11. Ran L, Chen X, Wang Y, Wu W, Zhang L, Tan X. Risk factors of healthcare workers with corona virus disease 2019: A retrospective cohort study in a dsignated hospital of Wuhan in China. Clin Infect Dis. 2020.

12. Wang W, Tang J, Wei F. Updated understanding of the outbreak of 2019 novel coronavirus (2019 nCoV) in Wuhan, China. J Med Virol. 2020;92:441-447.

13. Li Q, Guan X, Wu P, et al. Early Transmission Dynamics in Wuhan, China, of Novel Coronavirus-Infected Pneumonia. N Engl J Med. 2020;382(13):1199-1207.

Conflict of interest: none declared Financial support: none declared 